\title{
Moringa oleifera Impairs the Morphology and Functions of the Kidney in Adult Wistar Rats
}

\author{
Moringa Oleifera Altera la Morfología y Funciones del Riñón en Ratas Wistar Adultas
}

\begin{abstract}
Abdulazeez Adelaja Akinlolu*; Olaide Kamal Ghazali*; Oloduowo Mubarak Ameen**; Seunayo Comfort Oyebanji"; Gabriel Olaiya Omotoso* \& Bernard Ufuoma Enaibe*
\end{abstract}

\begin{abstract}
AKINLOLU, A. A.; GHAZALI, O. K.; AMEEN, O. M.; OYEBANJI, S. C.; OMOTOSO, G. O. \& ENAIBE, B. U. Moringa oleifera impairs the morphology and functions of the kidney in adult Wistar rats. Int. J. Morphol., 32(2):469-474, 2014.

SUMMARY: We tested the hypothesis that Moringa oleifera impairs the morphology and functions of the kidney in rats. Twentyfour adult male Wistar rats were employed in the study. Rats of Control Group I received physiological saline while rats of Groups II - IV received 250, 500 and $750 \mathrm{mg} / \mathrm{kg}$ bodyweight of methanolic extract of Moringa oleifera respectively for twenty one days. No behavioral anomalies were observed in rats of Groups I - IV. Rats of Control Group I gained statistically significant increased bodyweight while rats of Groups II - IV experienced non-significant decreased bodyweight during experimental procedure. ( $\mathrm{P} \leq 0.05)$. No statistical significant differences $(\mathrm{P} \leq 0.05)$ were observed in the analyses of the relative weights of kidneys of rats of Groups I - IV. Histological examinations showed normal cyto-architecture of the kidneys of rats of Group I while the Capsular spaces of the kidneys of rats of Groups II - IV appeared wider than those of Group I. Statistical analyses showed significant higher levels $(\mathrm{P} \leq 0.05)$ of Alanine and Aspartate Transaminases, and serum urea in rats of Groups II - IV in a non- dose-dependent manner when compared to rats of Group I. Our findings are consistent with the stated hypothesis.
\end{abstract}

KEY WORDS: Moringa oleifera; Toxicity profile; Kidney.

\section{INTRODUCTION}

Moringa oleifera or drumstick tree is a tropical plant widely known to be of possible great medicinal values (Fahey, 2005; Paliwal et al., 2011). It is a plant native to India, Pakistan, Bangladesh and Afghanistan and grows up to 5 or 10 meters in height. It is popularly called 'the miracle tree' with potentials for the treatment of various diseases such as cancer, hypertension and diabetes mellitus (Fahey; Paliwal et al.). Moringa oleifera's leaves have been traditionally used as antidiabetic, anti-bacterial, anti-headache, anti-hypertensive, antifever and anti-inflammatory herbal drug (Fahey; Paliwal et al.; Anwar et al., 2007). Various parts of the plant have been scientifically established to possess some medicinal properties such as abortifacient (root, flower and gum), anti-hypertensive (flower and seed), hypolipidemic (flower), anti-inflammatory (root and flower) and anti-ulcerogenic (stem bark) potentials (Fahey; Paliwal et al.; Anwar et al.).

Phytochemical screenings of different parts of Moringa oleifera revealed the presence of glucosinolates, isothiocyanates, carotenoids, vitamins, high proteins and carbohydrates (Fahey; Paliwal et al.; Anwar et al.; Junqueira $\&$ Carneiro, 2007). Hence, the plant is of high medicinal

\footnotetext{
* Department of Anatomy, University of Ilorin, Kwara State, Nigeria.

** Department of Chemistry, University of Ilorin, Kwara State, Nigeria.
}

and nutritive values to both humans and livestocks (Junqueira \& Carneiro). Moringa oleifera is well grown in different parts of Nigeria and its medicinal potentials are well recognized. Different institutions and agencies in Nigeria have, therefore, established Moringa oleifera plantations for public use. The University of Ilorin, Nigeria is one of such institutions with a well-established Moringa oleifera plantation providing powdered and non-powdered forms of its leaves for public usage.

The kidney is a major component of the urinary system, which maintains body homeostasis through filtration, active and passive absorption, and secretion. The final product of the filtration processes is urine which contains eliminated waste metabolic products. The kidneys are equally involved in the regulations of fluid and electrolyte balance, blood pressure and erythropoiesis (Junqueira \& Carneiro). The potential toxicity of medicinal plants is, however, of great concern (Adedapo et al., 2009). This study, therefore, tested the hypothesis that methanolic extract of Moringa oleifera leaves impairs the morphology and functions of the kidney in adult male Wistar rats. 


\section{MATERIAL AND METHOD}

Ethical approval. Ethical approval was sought and received from the Department of Anatomy of the University of Ilorin, Ilorin, Kwara State, Nigeria. The protocols for the use of animals in scientific research were strictly adhered to in compliance with World Health Organization's provisions.

Animal care and feeding. Twenty-four apparently healthy adult male Wistar rats weighing 100-200g obtained from the colony bred of the animal house of the Department of Veterinary Physiology, University of Ibadan, Oyo State, Nigeria were employed in the study. They were housed in individual cages in a well-ventilated and fumigated room with ambient temperature and good lighting. All rats were fed with standard pellet diet (Kusa Ventures Nigeria Limited, Ilorin) and received water ad libitum. The rats were acclimatized for seven days before the start of experimental procedures. The weight of each rat was taken daily. Furthermore, each rat was examined daily for possible behavioral and gross morphological or physical changes.

Chemicals, reagents and laboratory equipments. Normal saline solution, Phosphate buffer, EDTA, Sulphuric (VI) acid (H2SO4), Dimethyl sulfuroxide (DMSO) and hydrochloric acid (HCI) were products of BDH Chemical Limited, Poole, England; and assay kits for Alanine Transaminases (ALT), Aspartate Transaminases (AST) and Urea (Randox Laboratories, United Kingdom). Spectrophotometer (Jenway Model 6405, UV/visible), mortar and pestle, weighing balance, centrifuge, $\mathrm{pH}$ meter (Rex model pHs 25), Norm-jet needles and syringes (Norm-jet Inc. Tuttlinger, Germany) and anticoagulant tubes (Sterling products, England).

Collection and preparation of plant extracts. Moringa oleifera leaves were purchased from local traders at OjaTuntun, market of Ilorin, Kwara State, Nigeria. Harvested Moringa oleifera leaves were air - dried at room temperature $250 \mathrm{C}-300 \mathrm{C}$ for two weeks in order to prevent direct sunlight, which can react with the active ingredients of the plant. This prevented deterioration of the phytochemical constituents of the plant material. Dried pieces of the plant materials were pulverized and $1.2 \mathrm{~kg}$ of the dried sucker extracted with $70 \%$ methanol for 72 hours. The extract was filtered, concentrated with rotary evaporator and further dried on a water bath. The final product was gel-like and had a dark green color.

Administration of drugs/extract doses. The adult male Wistar rats $(n=24)$ were divided into four groups, each comprising of six rats. Rats of Group I received physiological saline. Rats of Experimental Groups II - IV received oral administrations of 250,500 and $750 \mathrm{mg} / \mathrm{kg}$ bodyweight of the methanolic extract of Moringa oleifera leaves respectively for twenty-one days (Days $1-21$ ).

Histological evaluations. The rats of Groups I - IV were sacrificed by cervical dislocation at the end of experimental procedures on Day 22. The thoracic and abdominal cavities of each rat were opened to excise and remove the kidney, and to obtain blood from the ventricles of the heart for histological and biochemical analyses. Histological examinations of the kidney were carried out using H-E techniques as earlier described (Akinlolu et al., 2008).

Average relative weight of kidneys of rats of Groups I IV at the end of experimental procedure. Prior to histological and biochemical evaluations, the excised kidneys of each rat of Groups I - IV were weighed and computed separately. The average relative weights of kidneys of rats in each of Groups I - IV were calculated on Day 22 at the end of experimental procedure using the formula stated below:

\section{Average Relative Weight of Kidney = Average Weight of Kidney/Average Bodyweight X 100.}

Evaluations of alanine and aspartate transaminases; and urea in kidney and sera samples of rats. The kidney of each rat was cut into small pieces, placed in a mortar and $0.1 \mathrm{M}$ phosphate buffer (extracting solution) of at least four times the volume of the organ was added. The organ was homogenized into fine solution with the use of mortar and pestle. The homogenate was poured into a test tube and centrifuged at 10,000 revolutions per minute for 10 minutes. The supernatant was carefully removed and the residue was discarded. The supernatant served as the sample for the estimations of Alanine Transaminases (ALT) and Aspartate Transaminases (AST) concentrations. Similarly, blood samples were centrifuged to separate the serum from the red blood cells and the serum was stored away for estimation of Urea concentrations.

Statistical Analyses. The Mean \pm S.E.M (S.E.M. = Standard Error of Mean) value of each of the measured parameters of kidney functions tests such as Alanine Transaminases (ALT), Aspartate Transaminases (AST) and Urea concentrations in rats of Control Group I were compared with rats of Experimental Groups II - IV any significant difference using the Student's t-test for unpaired samples. P values of 0.05 (or less) were taken as statistically significant. 


\section{RESULTS}

Changes in behavioral activities and average bodyweight ( $g$ ) of rats of control and experimental groups during experimental procedure. No behavioral anomalies were observed in rats of the Control and Experimental Groups I - IV during experimental procedure. Rats of Control Group I gained statistically significant increased bodyweight $(\mathrm{P} \leq 0.05)$ throughout the three weeks of experi-

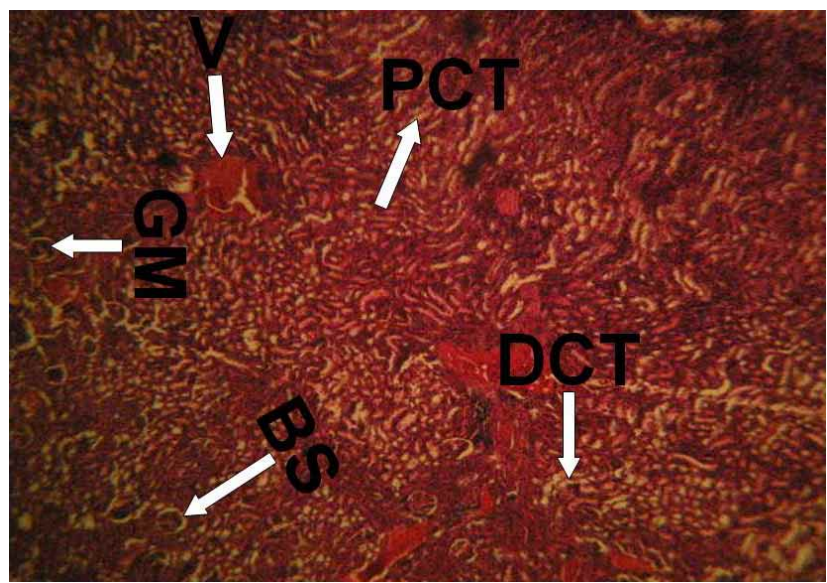

Fig. 1. Photomicrograph of the cortex and medullar of the kidney of rats of Group I which received physiological saline. Haematoxylin and Eosin X 100. GM = Glomeruli, BS = (Capsular space) Bowman's space, $\mathrm{PCT}=$ Proximal convoluted tubule, DCT $=$ Distal convoluted tubule and $\mathrm{V}=$ Vein. Renal corpuscle and spaces appeared well outlined. Glomeruli appeared non-clustered and well nucleated. Renal corpuscles and tubules appeared well distinct.

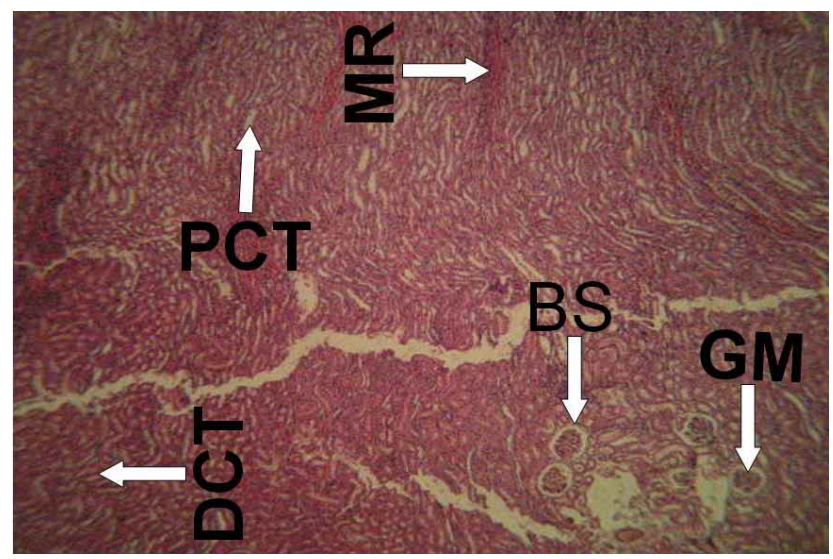

Fig.2. Photomicrograph of the cortex and medullar of the kidney of rats of Group II which received $250 \mathrm{mg} / \mathrm{kg}$ bodyweight of Moringa oleifera extract. Haematoxylin and Eosin X 100. GM = Glomeruli, MR $=$ Medullary rays, BS = (Capsular space) Bowman's space, PCT $=$ Proximal convoluted tubule and DCT $=$ Distal convoluted tubule. The capsular spaces appeared wider than those of the Control Group. The renal corpuscle, Glomeruli, Medullary rays, interlobular veins, Renal tubules and corpuscles appeared well outlined. mental procedure (Table I). In contrast, there was a progressive statistically non-significant decreased average bodyweight of rats of Groups II and IV during Days 1 - 10, however, from Days $10-22$, rats of Groups II and IV gained progressive statistically non-significant increased average bodyweight at $\mathrm{P} \leq 0.05$ (Table I). Rats of Group III experienced decreased average bodyweight beginning from

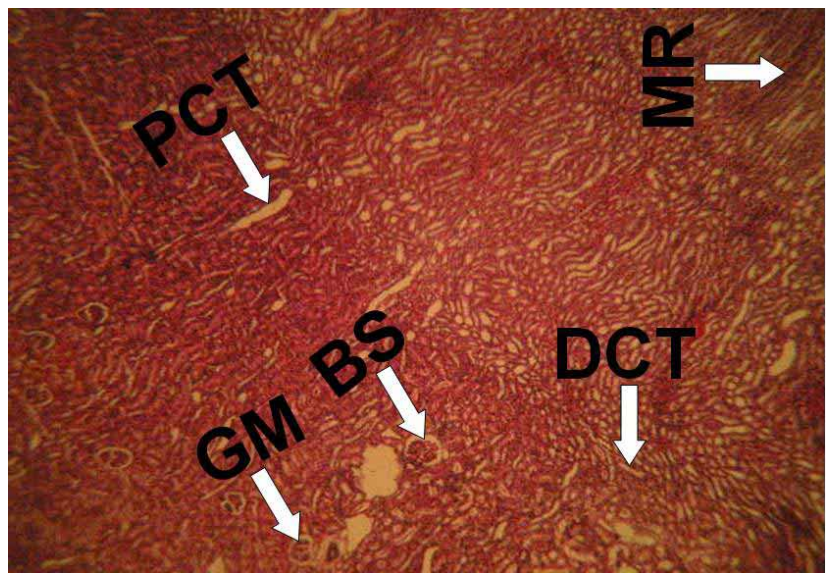

Fig. 3. Photomicrograph of the cortex and medullar of the kidney of rats of Group III which received $500 \mathrm{mg} / \mathrm{kg}$ bodyweight of Moringa oleifera extract. Haematoxylin and Eosin X 100. GM = Glomeruli, MR = Medullary ray, BS = (Capsular space) Bowman's space, $\mathrm{PCT}=$ Proximal convoluted tubule and DCT $=$ Distal convoluted tubule. The capsular spaces appeared wider than those of the Control Group. The Glomeruli, Medullary rays and Renal tubules appeared well outlined.

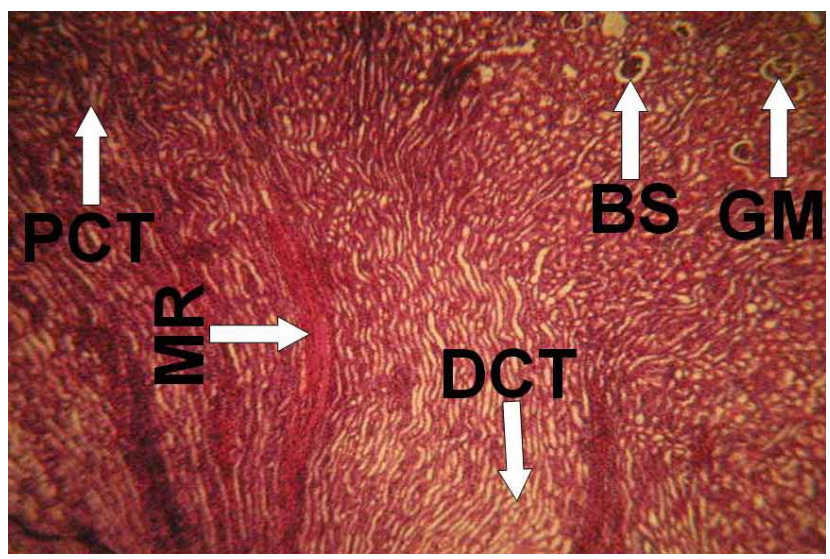

Fig. 4. Photomicrograph of the cortex and medullar kidney of rats of Group IV which received $750 \mathrm{mg} / \mathrm{kg}$ bodyweight of Moringa oleifera extract. Haematoxylin and Eosin X 100. GM = Glomeruli, MR = Medullary ray, $\mathrm{BS}=($ Capsular space $)$ Bowman's space, $\mathrm{PCT}=$ Proximal convoluted tubule and DCT $=$ Distal convoluted tubule. The capsular spaces appeared wider when compared to rats of the Control Group. Glomeruli appeared non-clustered with distinct renal corpuscles and tubules. Medullary rays and interlobular veins appeared well outlined. 
Day 1 till Day 22. Statistical analyses showed significant lower average bodyweight $(\mathrm{P} \leq 0.05)$ of rats of Group III on Day 1 when compared to Day 22 (Table I).

Evaluations of relative weight of kidneys of rats of control and experimental groups. Analyses of the Relative weight of Kidneys of rats of Experimental Groups II - IV showed no statistical significance when compared to rats of the Control Group I at $\mathrm{P} \leq 0.05$ (Table II).

Histological examinations of the kidneys of rats of control and experimental groups. Histological examinations showed normal cyto-architecture of the kidneys of rats of Control Group I. Comparative analyses showed that the capsular spaces of the kidneys of rats of Experimental Groups II - IV appeared wider than those of rats of Control Group I.
Evaluations of the activities of alanine and aspartate transaminases in the kidneys of rats of control and experimental groups. Statistical analyses showed significant higher activities $(\mathrm{P} \leq 0.05)$ of Alanine and Aspartate Transaminases in rats of Experimental Groups II - IV when compared to rats of Control Group I (Tables III and IV).

Evaluations of urea concentrations in the sera of control and experimental groups. Statistical analyses showed significant higher activities $(\mathrm{P} \leq 0.05)$ of Urea concentrations in the sera of rats of Experimental Groups II and III when compared to rats of Control Group I (Table V). However, no statistical significant difference was observed in the comparisons of urea concentrations in the sera of Control Group I and Experimental Group IV at $\mathrm{P} \leq 0.05$ (Table V).

Table I. Average relative weights of kidneys of rats of Groups I - IV during the experimental procedure.

\begin{tabular}{|c|c|c|c|c|c|c|c|c|c|}
\hline $\begin{array}{l}\text { Groups } \\
\text { of rats }\end{array}$ & Dose of drug/extract & $\begin{array}{c}\text { Day } 1 \\
\text { (g) }\end{array}$ & $\begin{array}{c}\text { Day } 4 \\
(\mathrm{~g})\end{array}$ & $\begin{array}{c}\text { Day } 7 \\
\text { (g) }\end{array}$ & $\begin{array}{c}\text { Day } 10 \\
(\mathrm{~g})\end{array}$ & $\begin{array}{c}\text { Day } 14 \\
\text { (g) }\end{array}$ & $\begin{array}{c}\text { Day } 17 \\
(\mathrm{~g})\end{array}$ & $\begin{array}{c}\text { Day } 21 \\
(\mathrm{~g})\end{array}$ & $\begin{array}{c}\text { Day } 22 \\
\text { (g) } \\
\end{array}$ \\
\hline $\mathrm{I}$ & Physiolological Saline & 135 & 137.1 & 139 & 142.5 & 146.2 & 148.9 & 149.5 & 150 \\
\hline II & $250 \mathrm{mg} / \mathrm{kg}$ bw Moringa oleif. & 113.1 & 111.9 & 111.6 & 114.0 & 116.5 & 120.2 & 121.4 & 122.4 \\
\hline III & $500 \mathrm{mg} / \mathrm{kg}$ bw Moringa oleif. & 135.6 & 131.6 & 127.1 & 125.6 & 122.8 & 119.5 & 116.1 & 115.4 \\
\hline IV & $750 \mathrm{mg} / \mathrm{kg}$ bw Moringa oleif. & 150.6 & 148.1 & 145.5 & 149.4 & 151.9 & 153.7 & 155.1 & 155.5 \\
\hline
\end{tabular}

bw = body weight, oleif. = oleifera.

Table II. Average relative weights of kidneys of rats of Groups I - IV on day 22 at the end of experimental procedure.

\begin{tabular}{|c|c|c|c|c|c|}
\hline $\begin{array}{l}\text { Group } \\
\text { of Rats }\end{array}$ & Dose of drug/extract & $\begin{array}{l}\text { AV. BW of Rats } \\
\text { on Day } 22(\mathrm{~g})\end{array}$ & $\begin{array}{l}\text { AVW of Kidney } \\
\text { on Day } 22(\mathrm{~g})\end{array}$ & RW of Kidney & $\begin{array}{c}\text { S. S. at P } \leq 0.05 \text { (Group I } \\
\text { vs. II - IV). }\end{array}$ \\
\hline I & Physiolological Saline & 150.0 & 1.20 & $0.8 \%$ & \\
\hline II & $250 \mathrm{mg} / \mathrm{kg}$ bw Moringa oleifera & 122.4 & 0.96 & $0.8 \%$ & NO \\
\hline III & $500 \mathrm{mg} / \mathrm{kg}$ bw Moringa oleifera & 118.4 & 1.00 & $0.9 \%$ & NO \\
\hline IV & $750 \mathrm{mg} / \mathrm{kg}$ bw Moringa oleifera & 154.5 & 1.14 & $0.7 \%$ & NO \\
\hline
\end{tabular}

$\mathrm{AV}=$ Average, $\mathrm{BW}=$ body weight, $\mathrm{RW}=$ Relative weight, S.S. = Statistical Significance.

Table III. Activities of alanine transaminase (ALT) in the kidneys of rats of Groups I - IV.

\begin{tabular}{lccc}
\hline $\begin{array}{l}\text { Group } \\
\text { of Rats }\end{array}$ & Dose of drug/extract & $\begin{array}{c}\text { Mean Level of } \\
\text { ALT (U/L) }\end{array}$ & $\begin{array}{c}\text { Statistical Significance at } \\
\text { P } \leq \mathbf{0 . 0 5} \text { (G roup I vs. II - IV). }\end{array}$ \\
\hline I & Physiological saline & $73.00 \pm 22.63$ & \\
II & $250 \mathrm{mg} / \mathrm{kg}$ bw Moringa oleifera & $128.33 \pm 66.34$ & YES \\
III & $500 \mathrm{mg} / \mathrm{kg}$ bw Moringa oleifera & $112.00 \pm 75.44$ & YES \\
IV & $750 \mathrm{mg} / \mathrm{kg}$ bw Moringa oleifera & $93.75 \pm 72.84$ & YES \\
\hline
\end{tabular}

bw $=$ bodyweight, ALT $=$ Alanine Transaminase.

Table IV. Activities of Aspartate Transaminase (AST) in the kidneys of rats of Groups I - IV.

\begin{tabular}{clcc}
\hline $\begin{array}{c}\text { Group } \\
\text { of Rats }\end{array}$ & \multicolumn{1}{c}{ Dose of drug/extract } & $\begin{array}{c}\text { Mean Level of } \\
\text { AST (U/L) }\end{array}$ & $\begin{array}{c}\text { Statistical Significance at } \\
\text { P } \leq \mathbf{0 . 0 5} \text { (Group I vs. II - IV). }\end{array}$ \\
\hline I & Physiological saline & $258.00 \pm 55.15$ & \\
II & $250 \mathrm{mg} / \mathrm{kg}$ bw Moringa oleifera & $775.67 \pm 46.21$ & YES \\
III & $500 \mathrm{mg} / \mathrm{kg}$ bw Moringa oleifera & $612.25 \pm 49.04$ & YES \\
IV & $750 \mathrm{mg} / \mathrm{kg}$ bw Moringa oleifera & $502.00 \pm 54.10$ & YES \\
\hline
\end{tabular}

bw = bodyweight, $\mathrm{AST}=$ Aspartate Transaminase. 


\begin{tabular}{cccc}
\multicolumn{2}{l}{ Table V. Urea concentrations in the sera of rats of Groups I - IV. } \\
\hline $\begin{array}{c}\text { Group } \\
\text { of Rats }\end{array}$ & Dose of drug/extract & $\begin{array}{c}\text { Mean Concentration } \\
\text { of Urea (U/L) }\end{array}$ & $\begin{array}{c}\text { S tatistical Significance at } \\
\text { P } \leq \mathbf{0 . 0 5} \text { (Group I vs. II - IV). }\end{array}$ \\
\hline I & Physiological saline & $19.03 \pm 4.62$ & YES \\
II & $250 \mathrm{mg} / \mathrm{kg}$ bw Moringa oleifera & $24.24 \pm 5.91$ & YES \\
III & $500 \mathrm{mg} / \mathrm{kg}$ bw Moringa oleifera & $30.48 \pm 13.55$ & NO \\
IV & $750 \mathrm{mg} / \mathrm{kg}$ bw Moringa oleifera & $19.44 \pm 3.01$ &
\end{tabular}

bw = bodyweight.

\section{DISCUSSION}

Moringa oleifera's leaves have been traditionally used as anti-diabetic, anti-bacterial, anti-headache, antihypertensive, anti-fever and anti-inflammatory herbal drug (Fahey; Paliwal et al.; Anwar et al.). It has been reported to contain abundant glucosinolates, isothiocyanates, carotenoids, vitamins, high proteins and carbohydrates (Fahey; Paliwal et al.; Anwar et al.; Junqueira \& Carneiro). Hence, when compared to some other plants, it is reported to be of higher nutritive values to both humans and livestock (Fahey; Thurber $\&$ Fahey, 2009). For example; "Gram for gram fresh leaves of Moringa oleifera have 4 times the vitamin A of carrots, 7 times the vitamin $\mathrm{C}$ of oranges, 4 times the calcium of milk, 3 times the potassium of bananas, $3 / 4$ the iron of spinach, and 2 times the protein of yogurt" (Fahey; Thurber \& Fahey).

Several Non Governmental Organizations such as the Trees for Life (USA), ECHO (Florida, USA), Church World Service (Indiana, USA), GIANT (Georgia, USA), Helen Keller International (Guinea) and Santé et Nature (Congo) have, therefore, promoted the nutritional benefits of Moringa oleifera around the world for the treatment of malnutrition (Fahey; Thurber \& Fahey). Due to cheap affordability by low-income earners, Moringa oleifera leaves have similarly been promoted as components of foods, nutritional supplements or medicines by patients with HIV/AIDS by several African governments (Monera et al., 2008) and as supplement to maize traditional complementary food to improve iron status in infants in Nigeria (Nnam, 2009). The widespread public use of Moringa oleifera leaves provides the reasons for the need to establish its safety and toxicological profile.

This study observed no behavioral anomalies in rats of Groups I - IV. This implied that Moringa oleifera leaves possibly had no adverse effects on body organs such as the cerebrum, cerebellum and the internal ear which control behavioral functions, equilibrium and balance. Rats of Control Group I gained statistically significant increased bodyweight while rats of Groups II - IV experienced nonsignificant decreased bodyweight during experimental procedure $(\mathrm{P} \leq 0.05)$. Furthermore, statistical analyses showed significant lower average bodyweight $(\mathrm{P} \leq 0.05)$ of rats of Group
III on Day 1 when compared to Day 22 (Table I). This is in agreement with previous studies which observed statistically significant decreased bodyweight $(\mathrm{p}<0.0001)$ in adrenalineinduced rats treated with $30 \mathrm{mg} / 155 \pm 15 \mathrm{gm}$ body weight of Moringa oleifera leaves (Ara et al., 2008).

No statistical significant differences (P£0.05) were observed in the analyses of the relative weights of kidneys of rats of Groups I - IV. This is in contrast with previous studies which observed statistically decreased weight of body organs such as the heart in rats treated with Moringa oleifera leaves when compared with the Control Group (Ara et al.). This implied that Moringa oleifera leaves possibly had no adverse effects on the gross morphology of the kidney as no gross anomalies were observed in the kidneys of rats of Groups I - IV. However, histological examinations showed normal cyto-architecture of the kidneys of rats of Group I while the capsular spaces of the kidneys of rats of Groups II - IV appeared wider than those of Group I. This is in contrast with a previous study which observed no adverse effects on the cytoarchitecture of body organs such as the liver in rats treated with Moringa oleifera leaves. (Adedapo et al.). Statistical analyses showed significant higher levels $(\mathrm{P} \leq 0.05)$ of Alanine and Aspartate Transaminases, and serum urea in rats of Groups II - IV in a non dose-dependent manner when compared to rats of Group I.

Alanine and Aspartate Transaminases are primary enzymes of the liver but are also present in the kidney (Nwangwu Spencer et al., 2011, Nwagwa, 2012). Elevated levels of Alanine and Aspartate Transaminases are, therefore, possible indicators of liver and kidney damage (Nwangwu Spencer et al.; Nwagwa). Similarly, urea concentrations provide one of the direct measurements of glomerular filtration rate and when elevated is indicative of kidney damage (Nwangwu Spencer et al.; Nwagwa). The observed elevated levels of urea, Alanine and Aspartate Transaminases implied that administrations of extract doses of Moringa oleifera leaves resulted in adverse effects on the blood filtration capacity of kidneys due to possible compromise of the integrity of glomerular membranes. 
This study concludes that Moringa oleifera impairs the morphology and functions of the kidney in adult Wistar rats. It is, therefore, advised that individuals consume Moringa oleifera's products in moderate quantities while concerted efforts should be made by Nigerian scientists to determine experimentally the required doses of the different parts of Moringa oleifera for safe nutritional and medicinal purposes.

AKINLOLU, A. A.; GHAZALI, O. K.; AMEen, O. M.; OYEBANJI, S. C.; OMOTOSO, G. O. \& ENAIBE, B. U. Moringa oleifera altera la morfología y funciones del riñón en ratas Wistar adultas. Int. J. Morphol., 32(2):469-474, 2014.

RESUMEN: Se puso a prueba la hipótesis que Moringa oleifera altera la morfología y función del riñón en ratas. Fueron utilizadas 24 ratas Wistar macho adultas. El grupo control recibió suero fisiológico mientras que los Grupos II a IV recibieron 250,500 y $750 \mathrm{mg} / \mathrm{kg}$ peso corporal del extracto metanólico de Moringa oleifera respectivamente, durante 21 días. No se observaron anomalías en el comportamiento en ratas de los Grupos I - IV. En las ratas del grupo de control se registró un aumento de peso corporal estadísticamente significativo, mientras que las ratas de los grupos II - IV experimentaron una disminución no significativa de peso corporal durante el procedimiento experimental $(\mathrm{P} \leq 0,05)$. No se observaron diferencias estadísticamente significativas $(\mathrm{P} \leq 0,05)$ en el análisis de los pesos relativos en riñones de las ratas de los grupos I - IV. Los exámenes histológicos mostraron citoarquitectura normal de los riñones de las ratas del grupo I, mientras que en ratas de los grupos II - IV los espacios capsulares de los riñones aparecían más amplios que los del Grupo I. Los análisis estadísticos mostraron niveles superiores significativos ( $\mathrm{P} \leq 0,05$ ) de la alanina y aspartato aminotransferasa, y de urea en suero en ratas de los Grupos II - IV - no dependiente de la dosis, en comparación con las ratas del Grupo I. Estos resultados coinciden con la hipótesis planteada.

PALABRAS ClAVE: Moringa oleifera; Perfil de toxicidad; Riñón.

\section{REFERENCES}

Adedapo, A. A.; Mogbojuri, O. M. \& Emikpe, B. O. Safety evaluations of the aqueous extract of the leaves of Moringa oleifera in rats. J. Med. Plants Res., 3(8):586-91, 2009.

Akinlolu, A. A.; Ayoola, M. D.; Otulana, J. O.; Akinola, O. B.; Olayiwola, A. \& Ejiwunmi, A. B. Evaluation of the histo gastroprotective and antimicrobial activities of Heliotropium indicum linn (boraginaceae). Malays. J. Med. Sci., 15(3):2230, 2008.

Anwar, F.; Latif, S.; Ashraf, M. \& Gilani, A. H. Moringa oleifera: a food plant with multiple medicinal uses. Phytother. Res., 21(1):17-25, 2007.

Ara, N.; Rashid, M. \& Amran, S. Comparison of Moringa oleifera leaves extract with Atenolol on serum triglyceride, serum cholesterol, blood glucose, heart weight, body weight in Adrenaline Induced Rats. Saudi J. Biol. Sci., 15(2):253-8, 2008.

Fahey, J. W. Moringa oleifera: Moringa oleifera: A review of the medical evidence for its nutritional, therapeutic, and prophylactic properties. Part 1. Trees for Life Journal. 2005. Disponible en: http://www.tfljournal.org/article.php/ 20051201124931586

Junqueira, L. C. \& Carneiro, J. Basic Histology: Text \& Atlas. 11th ed. New York, McGraw-Hill, 2007. Chapter 19.

Monera, T. G.; Wolfe, A. R.; Maponga, C. C.; Benet, L. Z. \& Guglielmo, J. Moringa oleifera leaf extracts inhibit 6betahydroxylation of testosterone by CYP3A4. J. Infect. Dev. Ctries., 2(5):379-83. 2008.
Nnam M. N. Moringa oleifera leaf improves iron status of infants 6-12 months in Nigeria. Int. J. Food Saf. Nutr. Public Health, 2(2):158-64, 2009.

Nwangwa, E. K. The reno-protective effects of coconut water on the kidneys of diabetic wistar rats. J. Health Sci., 2(1):1-4, 2012.

Nwangwu Spencer, C. O.; Josiah Sunday, J.; Abubakar Teslimat, E.; Ajeigbe Kazeem, O.; Osakwe Eguagie, O. \& Akintola Akinola, A. Comparative effects of aqueous and ethanolic leaf extracts of gongronema latifolium on serum, kidney and liver biomarkers of normal male rats. Asian J. Biol. Sci., 4(7):5407. 2011.

Paliwal, R.; Sharma, V.; Pracheta; Sharma, S.; Yadav, S. \& Sharma, S. Anti-nephrotoxic effect of administration of Moringa oleifera Lam in amelioration of DMBA-induced renal carcinogenesis in Swiss Albino mice. Biol. Med., 3(2):27-35, 2011.

Thurber, M. D. \& Fahey, J. W. Adoption of Moringa oleifera to combat under-nutrition viewed through the lens of the "Diffusion of innovations" theory. Ecol. Food Nutr., 48(3):21225, 2009.

Correspondence to:

Akinlolu Abdulazeez Adelaja

Department of Anatomy

Faculty of Basic medical Sciences

University of Ilorin, Ilorin

Kwara State

NIGERIA

Received: 25-05-2013

Accepted: 30-03-2014

Email: a3akin@gmail.com 